\title{
THE EFFECT OF HOMALANTHUS POPULNEUS (GIESEL.) PAX. EXTRACT IN EXPRESSION OF T-CELL RECEPTOR: INHIBITION STUDY OF HIV INFECTION
}

\author{
SINTYA E. ${ }^{1 *}$, WIJAYANTI N. ${ }^{2}$, NORAENI A. ${ }^{3}$ \\ ${ }^{1}$ Department of Physiology and Biochemistry, Faculty of Medicine and Health Science, Warmadewa University, Denpasar, Bali, Indonesia. \\ ${ }^{2}$ Department of Biology, Faculty of Biology, Gadjah Mada University, Yogyakarta, Indonesia. ${ }^{3}$ Institute of Human Virology and Cancer \\ Biology, University of Indonesia.*Email: erlysintyadewi@gmail.com
}

Received: 24 February 2019, Revised and Accepted: 21 July 2019

ABSTRACT

Objective: The aim of this study is to analyze the effect of Homalanthus populneus's extract toward the expression of CD4 and CD8 which both are important in body's defense mechanism against HIV.

Methods: Leaves and barks of H. populneus were extracted with $70 \%$ ethanol. Freeze dry method had been used in order to get the final extract. PBMCs were extracted and it has been used for CD4 and CD8 expression test using flow cytometry. In oreder to analyze the effect of the extract to the HIV type 1, gp41 and gp120 expression was tested using talicytometry and using enzyme-linked immunosorbent assay, respectively.

Results: This study reported that H. populneus's extract reduced the expression of CD4 receptor in both peripheral blood mononuclear cell (PBMC) and T-lymphoblast cell line (CEM). In contract, this extract increased CD8 expression in PBMC. It was also able to reduce the percentage of protein gp41 and gp120 in CEM cultures.

Conclusion: Those results show that H. populneus's extract is potentially developed as an HIV drug from Indonesia. However, further study needs to be done including analyzing the effect of variety of concentrations and also exposure periods.

Keywords: Homalanthus populneus, CD4, CD8, HIV.

(c) 2019 The Authors. Published by Innovare Academic Sciences Pvt Ltd. This is an open access article under the CC BY license (http://creativecommons. org/licenses/by/4. 0/) DOI: http://dx.doi.org/10.22159/ijap.2019.v11s5.T0106

\section{INTRODUCTION}

Prostratin is a secondary metabolite of plants which is endemic in the Samoa Islands (South Pacific Ocean Islands) named Homalanthus nutans $[1,2]$. Prostratin can activate the expression of HIV-1 in cells infected with HIV by increasing viral replication but not followed by an increase in cell division; thus, these cells produce new viruses that can be recognized by immunocompetent cells [3]. Prostratin also inhibits the expression of chemokine receptors in helper $\mathrm{T}$ cells, which are the entry points for viruses into lymphocytes $[4,5]$. In Indonesia, there are plants which have same genus category as Homalanthus nutans, called Homalanthus populneus. This plant is spread abundantly in Indonesia. In the previous studies, it was known that this plant contained prostratin [6] and was able to reduce the expression of cluster of differentiation (CD4) receptors up to $82.84 \%$ in normal cells [6]. Prostratin from $H$. populneus is potential to be developed as an anti-HIV drug from Indonesia. Therefore, it is necessary to test to determine the effectiveness of this local prostratin in inhibiting HIV infection by inhibiting the expression of $\mathrm{T}$ helper. This study also wants to analyze the effect of ethanol extract of $H$. populneus to the expression of HIV by calculating its capsid proteins which are gp120 and gp41.

\section{MATERIALS AND METHODS}

\section{Reagents}

Ethanol extracts of leaves and bark of H. populneus (Giesel.) Pax. from the previous study had been used in this research. The concentration of prostratin had been measured with high-performance liquid chromatography method. Monoclonal antibody to CD4 and CD8 was purchased from Thermo Fisher Scientific (Waltham, USA). HIV-1 gp41 and gp120 antibodies were purchased from LSBio (LifeSpan BioScience, Inc., North America).

\section{Peripheral blood mononuclear cell (PBMC) preparation}

PBMCs were isolated from $15 \mathrm{ml}$ blood of healthy donors using centrifugations. Roswell Park Memorial Institute (RPMI) was added to the blood sample with ratio 1:1. Ficoll-Paque Plus (Sigma-Aldrich, Darmstadt, Germany) was utilized to collect PBMC from blood. Before blood mixed with Ficoll, RPMI was added until $30 \mathrm{ml}$ (Sigma-Aldrich, Darmstadt, Germany). Comparison of Ficoll Plus and blood sample was $3 \mathrm{ml}: 8 \mathrm{ml}$. After that, it was centrifuged for $20 \mathrm{~min}, 400 \mathrm{D}$, at $18^{\circ} \mathrm{C}$. The formed buffi coat was separated and then mixed with RPMI up to $13 \mathrm{ml}$. It was then centrifuged for $10 \mathrm{~min}$ at $18^{\circ} \mathrm{C}$ and at $400 \mathrm{D}$. The deposited pellets were mixed with $4 \mathrm{ml}$ complete medium. Finally, lymphocyte cells were counted using Neubauer hemocytometer method.

\section{PBMCs proliferation test}

PBMC proliferation test was carried out by 3-(4,5-dimethylthiazol2-yl)-2,5-diphenyltetrazolium bromide (MTT) assay. PBMC cells that were mixed with a complete medium $(2 \mathrm{ml}$ of penicillin-streptomycin, $0.5 \mathrm{ml}$ of fungison, and $80 \mathrm{ml}$ of RPMI, all were purchased from SigmaAldrich, Darmstadt, Germany) were incubated for $24 \mathrm{~h}$ at $37^{\circ} \mathrm{C}$ and $5 \% \mathrm{CO}_{2}$ in a well microplate 96 . Cell density in each well is $1 \times 10^{5}$ cells $/ 100 \mathrm{ml} /$ well. Six different concentrations of the ethanol extracts of $H$. populneus's barks (B) and leaves (D) were used in this study $(0.125,0.5,1,62.5,125$, and $250 \mu \mathrm{g} / \mathrm{ml})$. At the end of the incubation period, $10 \mathrm{ml}$ of $5 \mathrm{mg} / \mathrm{ml}$ MTT (Invitrogen, Thermo Fisher Scientific, Waltham, USA) was added to each well. Cell suspension was then incubated at $37^{\circ} \mathrm{C}, 5 \% \mathrm{CO}_{2}$ for $4 \mathrm{~h}$. The reaction was stopped by adding 1\% Safety Data Sheet (Invitrogen, Thermo Fisher Scientific, Waltham, USA) in $0.1 \mathrm{~N} \mathrm{HCl}$ (Sigma-Aldrich, Darmstadt, Germany) as much as $10 \mathrm{ml} /$ well. The absorbance value was read using enzyme-linked immunosorbent assay (ELISA) reader (LABOMED, Los Angeles, USA) with a wavelength of $550 \mathrm{~nm}$. 
Transfection PNL43 plasmid

The first solution was lipofectamine, $7.5 \mu \mathrm{l}$ of lipofectamine 3000 (Invitrogen, Thermo Fisher Scientific, Waltham, USA) was dissolved in $250 \mu \mathrm{l}$ medium Opti-MEM (Invitrogen, Thermo Fisher Scientific, Waltham, USA). The second solution, the master mix DNA, $5 \mu \mathrm{g}$ of DNA was dissolved with $250 \mu \mathrm{l}$ of Opti-MEM medium. The first and second solutions were mixed and incubated for $5 \mathrm{~min}$. This cDNA-lipid complex was added to cell culture with green fluorescent protein (Invitrogen, Thermo Fisher Scientific, Waltham, USA) on flask 25, incubate 3 days; then, it was observed under a fluorescent microscope, whether the cell is fluorescent (transfection successful) or not (transfection fails).

\section{ELISA}

105/100 ul cells with PNL43 were planted in in plate 96-well with six replications and incubated for 1 day. Three different concentrations of the ethanol extracts of $H$. populneus's barks were used in this study $(7,11$, and $15 \mu \mathrm{g} / \mathrm{ml})$. Bark extract had been chosen rather than leave extract since bark extract contains higher concentration of prostratin. After adding the extract, the cells were incubated at $37^{\circ} \mathrm{C}$ with $5 \% \mathrm{CO}_{2}$ for 3 days. The ELISA test was then carried out using gp 41 antibodies.

\section{Flow cytometry and Tali Image-based Cytometer}

The PBMC cells were incubated on the well microplate 24 with a density of $45 \times 10^{4}$ cells $/ 100 \mathrm{ml} /$ well. Three different concentrations of the ethanol extracts of $H$. populneus's barks were used in this study $(7.8,15.6$, and $31.2 \mu \mathrm{g} / \mathrm{ml})$. Cells that have been given treatment are then incubated again for $24 \mathrm{~h}$. After that, it was harvested using phosphate-buffered saline (PBS) and centrifuged gradually with a speed of $2000 \mathrm{rpm}$ for $25 \mathrm{~min}$ at $4^{\circ} \mathrm{C}$. Harvested cells were suspended into PBS to $0.5 \mathrm{ml}$ in a $1.5 \mathrm{ml}$ microtube. After that, it was added with $10 \mu \mathrm{l}$ antibodies (gp120, mixture of CD4 and CD8), then incubated for 15 min in the dark room. Then, PBS (Thermo Fisher Scientific, Waltham, USA) was added and it was centrifuged again at $1500 \mathrm{rpm}$ for $5 \mathrm{~min}$. The pellets were added with $1 \mathrm{ml}$ of fluorescence-activated cell sorting flow. Then, one by one measured the percentage of CD4 and CD8 counts using flow cytometry [7] (Becton Dickinson, Calif., USA). To detect the concentration of gp120, Tali Image-based Cytometer was utilized.

\section{RESULTS}

Ethanolic extract of $\boldsymbol{H}$. populneus induces PBMCs replication PBMCs were obtained from women aged 21/22 years who had no previous history of severe illness. In this study, from $12 \mathrm{ml}$ blood, $6.5 \times 10^{6}$ cells $/ \mathrm{ml}$ PBMC were obtained. PBMCs from collected blood must be isolated immediately to prevent blood clots. Proliferation test was carried out using PBMC as much as $1 \times 10^{5}$ cells $/ 100 \mu \mathrm{l}$ in each microplate well 96 . Administration of ethanol extract from barks causes an increase in the number of lymphocytes from the total cells obtained. Bark extract with a concentration of $7.8 \mu \mathrm{g} / \mathrm{ml}$ did not able to raise the number of lymphocytes which amounted to $71.3 \%$. However, the administration of ethanol extract from the bark with a concentration of $15.6 \mu \mathrm{g} / \mathrm{ml}$ increased the number of lymphocyte cells to $91.5 \%$ while the concentration of $31.2 \mu \mathrm{g} / \mathrm{ml}$ caused the lymphocyte count to be $95.23 \%$ of the total cells gathered. Comparison of the number of lymphocytes produced can be shown from Fig. 1.

The stopper was added to dissolve the formazan crystals that were formed so the cultures that contain many living cells will turn to be purple. The colorimetric results of this optical density correspond to the number of living cells. This method is very sensitive. The proliferation test results in this study are shown in Fig. 1.

Table 1 shows the specific level of prostratin which causes the proliferation happened. It can be seen that the bark extract contains higher concentration of prostratin compared to leaves extract; therefore, only bark extract that was used for the next tests.

\section{Ethanolic extract of $H$. populneus downregulated CD4 and upregulated CD8}

Cytometric flow readings are scattergrams that are the result of forward scatter and side scatter. Gating was done to select more specific cell groups based on the expression of CD4 and CD8. Before test, $5 \mu \mathrm{l} / \mathrm{ml}$ anti-CD3 was added. The presence of this CD3 receptor will interfere the bonding between T-cell receptor (TCR) and antigenpresenting cell (APC), so anti-CD3 is needed. No disruption of TCR-APC bonding will accelerate the process of interleukin-2 (IL2) formation in PBMC cultures. IL2 itself plays a major role in regulating the process of proliferation and differentiation of $\mathrm{T}$ cells.

Fig. 2 shows that there was a possibility that the PBMC culture contained not only lymphocytes but also monocytes. Analysis using CD4 and CD8 monoclonal antibodies showed that the number of lymphocyte cells from the total cells obtained was $71.3 \%$ in cell control and $70.4 \%$ in solvent control. The number of lymphocyte cells in cell control and solvent control was not much different; this showed that DMSO solvents with a concentration of $31.2 \mu \mathrm{l} / \mathrm{ml}$ were not toxic to PBMC cells. Hence, it can be estimated that the decrease in the percentage of CD4 or CD8 receptors not caused by solvents which in this study was DMSO.

\section{Ethanolic extract of H. populneus downregulated protein gp41 and gp120}

In this test, previously labeled antibodies, gp41 (for HIV-1 capsid protein) was used. Test was carried out on cell cultures that were positively transfected by PNL4-3 plasmids. The concentrations of bark extract that was used in this test were 7,11 , and $15 \mu \mathrm{g} / \mathrm{ml}$. The results of the Tali Image-based Cytometer test are shown in Fig. 3.

Furthermore, to quantify the gp120 expression, ELISA method was used. Before coating to the well plate $96,1 \%$ formaldehyde was added to the culture cell, the purpose of which was to lyse the cell wall so that the gp120 antibodies could bind to the gp120 antigen within the cell. After that, cells in well plate 96 were incubated overnight at $40^{\circ} \mathrm{C}$ to give sufficient time so that all the gp120 antigens that have been coated can

Table 1: Prostratin concentration in ethanolic extracts of leaves and bark of $H$. populneus and percentage of PBMC proliferation effects caused by it

\begin{tabular}{|c|c|c|c|}
\hline Test and extract type & Concentration $(\mu \mathrm{g} / \mathrm{ml})$ & Level of prostratin $(\mu \mathrm{g} / \mathrm{ml})$ & Average proliferation (\%) \\
\hline \multirow[t]{6}{*}{ PBMCs proliferation test by adding leaves extract } & 250 & 4.9 & 125.9 \\
\hline & 125 & 2.5 & 81.6 \\
\hline & 62.5 & 1.2 & 53.6 \\
\hline & 1 & 0.3 & 17.6 \\
\hline & 0.5 & 0.2 & 7.4 \\
\hline & 0.125 & 0.02 & 0.8 \\
\hline \multirow[t]{6}{*}{ PBMCs proliferation test by adding bark extract } & 250 & 19 & 143 \\
\hline & 125 & 9.5 & 95.3 \\
\hline & 62.5 & 4.7 & 70.7 \\
\hline & 1 & 1.2 & 27.6 \\
\hline & 0.5 & 0.6 & 13.5 \\
\hline & 0.125 & 0.1 & 3.7 \\
\hline
\end{tabular}

H. populneus: Homalanthus populneus, PBMC: Peripheral blood mononuclear cell 

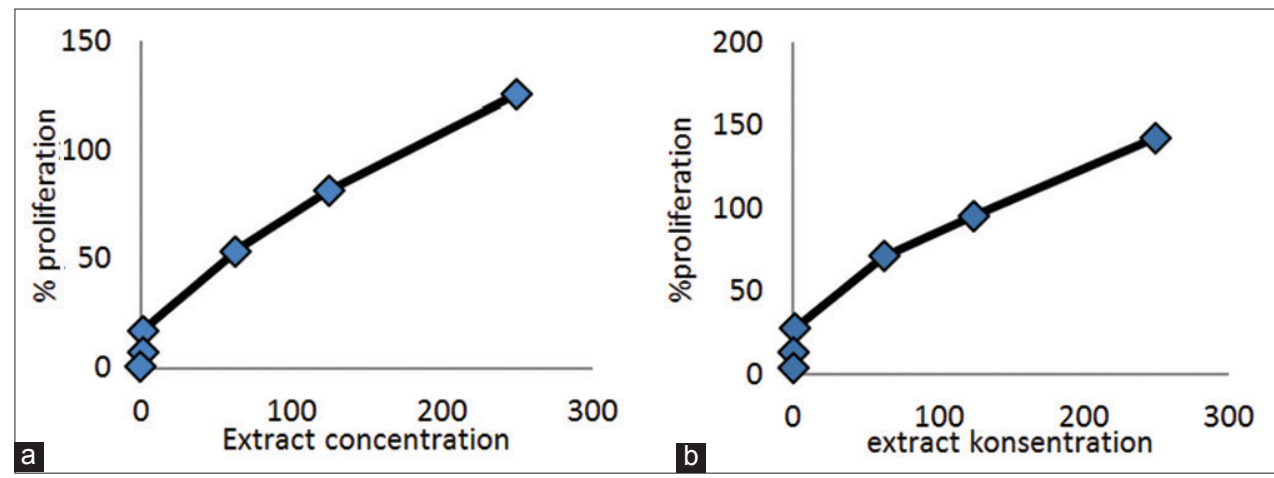

Fig. 1: The average percentage of peripheral blood mononuclear cells proliferation by adding ethanolic extract of leaves (a) and bark (b) of Homalanthus populneus with concentrations of 0.125, 0.5, 1, 62.5, 125, and $250 \mu \mathrm{g} / \mathrm{ml}$ and controls

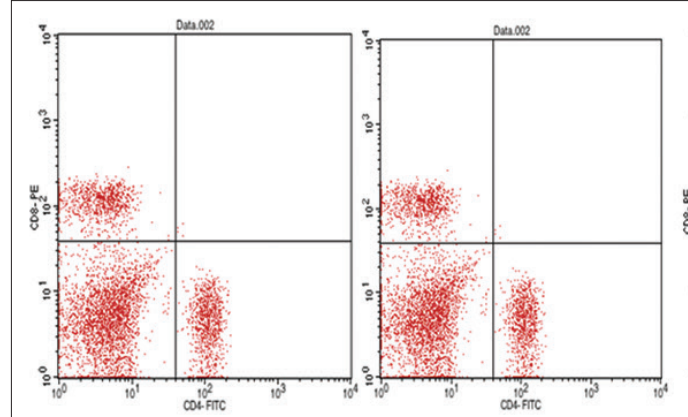

a b

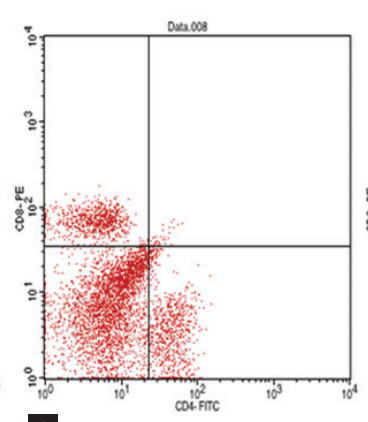

c

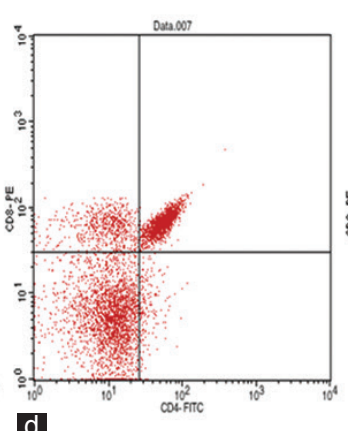

d

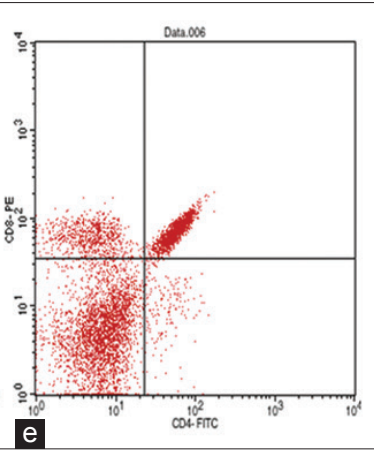

Fig. 2: The results of flow cytometry using cluster of differentiation (CD8) and CD4 antibodies on peripheral blood mononuclear cell without extract, (a) control cell, (b) solvent only, and with ethanol extract of Homalanthus populneus's bark, (c) $7.8 \mu \mathrm{g} / \mathrm{ml},(\mathrm{d}) 15.6 \mu \mathrm{g} / \mathrm{ml}$, and (e) $31.2 \mu \mathrm{g} / \mathrm{ml}$

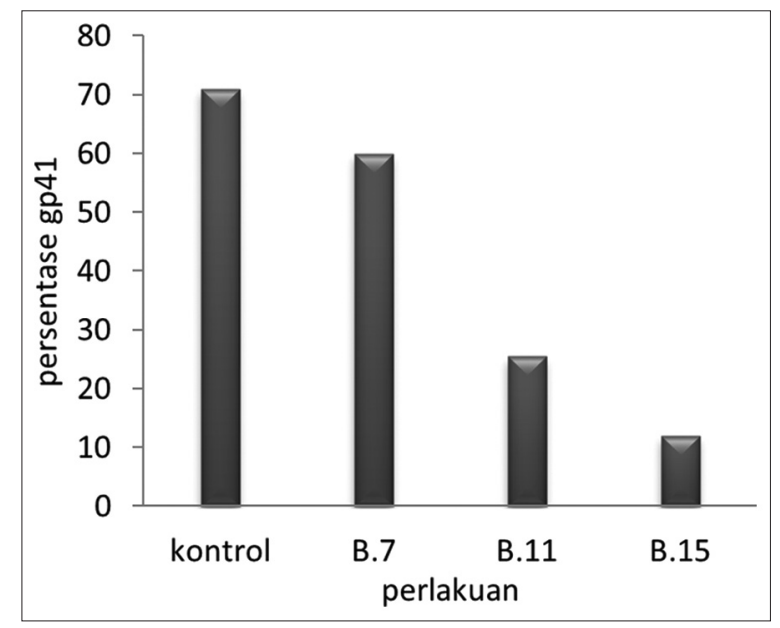

Fig. 3: Percentage of gp41 using Tali image-based cytometer test with two replications

bind to the first and second gp120 antibodies. The result of ELISA test can be shown in Table 2.

\section{DISCUSSION}

MTT is used to qualitatively viability cell based on mitochondria metabolic activity used by the cells. The process of MTT assay is based on transformation of tetrazolium salt (MTT) into formazan crystals. MTT, dissolved in PBS, will be absorbed to the viable cell by the existing gradient concentration of solution inside and outside the cell (solution in the cell is more thick). Next, yellow-colored tetrazolium salt is reduced by complex enzyme of succinate dehydrogenase, which is
Table 2: The ELISA test results using gp 120 antibodies with three different concentrations of bark extract

$(7,11$, and $15 \mu \mathrm{g} / \mathrm{ml})$

\begin{tabular}{lllll}
\hline Concentration of the extract $(\boldsymbol{\mu g} / \mathbf{m l})$ & $\mathbf{0}$ & $\mathbf{7}$ & $\mathbf{1 1}$ & $\mathbf{1 5}$ \\
\hline Presentation of gp 120 protein & 92 & 81 & 77 & 72 \\
\hline ELISA: Enzyme-linked immunosorbent assay & & & &
\end{tabular}

Table 3: Prostratin levels at the concentrations of the ethanol extracts of leaves and bark of $H$. populneus based on previous HPLC data

\begin{tabular}{lll}
\hline $\begin{array}{l}\text { Type of } \\
\text { extract }\end{array}$ & Konsentration $(\boldsymbol{\mu g} / \mathbf{m l})$ & Level of prostratin $(\boldsymbol{\mu g} / \mathbf{m l})$ \\
\hline Leaves & 7.8 & 0.1 \\
extract & 15.6 & 0.3 \\
& 31.2 & 0.6 \\
Bark & 7.8 & 0.6 \\
extract & 15.6 & 1.2 \\
& 31.2 & 2.4 \\
\hline
\end{tabular}

H. populneus: Homalanthus populneus, HPLC: High-performance liquid chromatography

active when metabolic process occurred in mitochondria [3]. The aim of the stopper is to dissolve the formed formazan crystals so that the culture contains abundant viable cell with purple color [3]. Increasing percentage of proliferation (number) of PBMCs is comparable directly with increasing concentration of tested compound. The results showed that tested compound did not cause death against PBMC, but instead, it induced PBMC proliferation. 
Table 4: Percentage of CD4 cells and CD8 results from flow cytometry

\begin{tabular}{lll}
\hline Concentration & CD4+(\%) & CD8 $^{+}(\%)$ \\
\hline $\mathrm{K}^{*}$ & 50.2 & 49.7 \\
K. DMSO & 50.8 & 49.1 \\
$\mathrm{~B}^{* *} .31 .2 \mu \mathrm{g} / \mathrm{ml}$ & 18.8 & 81.2 \\
B. $15.6 \mu \mathrm{g} / \mathrm{ml}$ & 22.5 & 77.5 \\
B. $7.8 \mu \mathrm{g} / \mathrm{ml}$ & 48.9 & 51 \\
\hline
\end{tabular}

${ }^{*} \mathrm{~K}=$ Control, ${ }^{* *} \mathrm{~B}=$ Bark extract, $\mathrm{CD}$ : Cluster of differentiation

Difference effects on the ethanol extract of leaves and bark could be caused by smaller concentration of prostratin in the leaves than bark. Estimation of prostratin concentration for all extract concentrations from leaves and bark of $H$. populneus is served in Table 3 .

Flow cytometry results show that CD4 cell and CD8 expression in cells with bark extract of $H$. populneus at the concentration of $7.8 \mu \mathrm{g} / \mathrm{ml}$ was not different from cell control, whereas the concentrations of 15.6 and $31.2 \mu \mathrm{g} / \mathrm{ml}$ bark extract reduced CD 4 and increased CD8 expression compared to controls (Table 4).

In this study, the results show that ethanol extracts of bark at concentrations of $31,15.6$, and $7 \mu \mathrm{g} / \mathrm{ml}$ could increase the number of $\mathrm{CD}^{+}$cells. This may be because prostratin can activate HIV-1 expression in HIV-infected cells so that these cells produce new viruses. As a result of being activated, the HIV will induce the expression of cellular proteins and will be considered an abnormal protein within the cell. Furthermore, this protein will be recognized and degraded into small peptides which will be released in the cytosol by proteasome. These peptides will be translocated from the cytosol to the endoplasmic reticulum to meet with Class I major histocompatibility complex (MHC) molecules. The translocation of peptides from the cytosol to the RE is aided by transporter associated with antigen processing. This peptide will be enveloped by secretory vesicle, and then, it will fuse with the cell membrane. Since HIV is activated by the prostratin, many MHC Class I were presented on the cell surface, this condition will induce naive $\mathrm{T}$ cells to differentiate and proliferate into $\mathrm{CD} 8^{+}$cells so that the number of $\mathrm{CD} 8^{+}$cells increases compared to controls. CD8 ${ }^{+}$ cells will release proteins called perforin which can attack target cells. Perforin will make a kind of pore on the target cell membrane so that granzyme can enter into the target cell and induce apoptosis.

According to Biancotto et al. [4], there are several mechanisms in the process of decreasing HIV regulation in cell culture in vitro, namely:

1. Reducing the regulation of CD4 receptors $[4,8]$

2. Inhibiting virus entry into cells by decreasing the regulation of receptors [9]

3. Inhibiting the completeness of the virus reverse transcription process [10].

In addition, research involving the internalization process of p24gag also showed that prostratin inhibits HIV entry through a decrease in CD4 regulation. Therefore, the ongoing infection in cells will also be hampered [4,11-13]. In this study also demonstrates a decrease in the number of gp41 antigens in cell culture, indicating that ethanol extract of the bark containing prostratin can inhibit HIV activity in cells (direct inhibition) and/or prostratin inhibits regulation of HIV receptors, thereby inhibiting HIV infiltration into T cells.

Gp120 and gp41 are both capsid proteins of the HIV whose position is attached to each other but has different functions in the mechanism of HIV infiltration. The gp120 protein binds to CD4, the gp120-CD4 complex will bind to the CCR5 or CXCR4 chemokine receptors [14-17]. When this bond is formed, the gp120 stretches and provides room for fusion between the host cell membrane and gp 41 which acts to transfer the HIV genetic material into the host cell. Hence, the performances of gp120 and gp41 are very important and related to one another. Therefore, these two types of proteins can be linked as markers of the presence of the HIV in the host cell.

\section{CONCLUSION}

Plant extract of $H$. populneus (Giesel.) Pax. can reduce the percentage of helper T cells and increase the percentage of cytotoxic T cells in human PBMC. The results of testing using cell cultures showed that administration of ethanol stem extract of the bark of $H$. populneus was able to reduce the percentage of CD4 expression and reduce the amount of HIV formed in positive cell cultures infected with HIV. Therefore, it can be concluded that this plant is potential to be an effective source of prostratin. Further research needs to be done to obtain optimal concentrations of this extract as a potential anti-HIV drug from Indonesia.

\section{REFERENCES}

1. Gustafson KR, Cardellina JH $2^{\text {nd }}$, McMahon JB, Gulakowski RJ, Ishitoya J, Szallasi Z, et al. A nonpromoting phorbol from the samoan medicinal plant Homalanthus nutans inhibits cell killing by HIV-1. J Med Chem 1992;35:1978-86.

2. Johnson HE, Banack SA, Cox PA. Variability in content of the antiAIDS drug candidate prostratin in Samoan populations of Homalanthus nutans. J Nat Prod 2008;71:2041-4

3. Goel G, Makkar HP, Francis G, Becker K. Phorbol esters: Structure, biological activity, and toxicity in animals. Int J Toxicol 2007;26:279-88

4. Biancotto A, Grivel JC, Gondois-Rey F, Bettendroffer L, Vigne R, Brown $\mathrm{S}$, et al. Dual role of prostratin in inhibition of infection and reactivation of human immunodeficiency virus from latency in primary blood lymphocytes and lymphoid tissue. J Virol 2004;78:10507-15.

5. Korin YD, Brooks DG, Brown S, Korotzer A, Zack JA. Effects of prostratin on T-cell activation and human immunodeficiency virus latency. J Virol 2002;76:8118-23.

6. Fatimah A, Isnan M, Nirwantono R, Haryatfrehni R. Identifikasi Senyawa Prostratin pada Tumbuhan Homalanthus populneus di Indonesia Sebagai Anti Virus HIV-AIDS. Yogyakarta: Laporan Penelitian PKM Fakultas Biologi UGM; 2012.

7. Brown M, Wittwer C. Flow cytometry: Principles and clinical applications in hematology. Clin Chem 2000;46:1221-9.

8. Kulkosky J, Culnan DM, Roman J, Dornadula G, Schnell M, Boyd MR, et al. Prostratin: Activation of latent HIV-1 expression suggests a potential inductive adjuvant therapy for HAART. Blood 2001;98:3006-15.

9. Law MG, Li Y, McDonald AM, Cooper DA, Kaldor JM. Estimating the population impact in Australia of improved antiretroviral treatment for HIV infection. AIDS 2000;14:197-201.

10. McGowan JP, Sanjiv S. Understanding HIV Tropism; 2010. Available from: http://www.prn.org/index.php/management/article/hiv_tropism_1002. [Last accessed on 2014 Oct 01].

11. Fanales-Belasio E, Raimondo M, Suligoi B, Buttò S. HIV virology and pathogenetic mechanisms of infection: A brief overview. Ann Ist Super Sanita 2010;46:5-14.

12. Campbell NA, Reece JB, Mitchell LG, Taylor MR. Biology. $4^{\text {th }}$ ed. San Fransisco: Addison Wesley World Student Series; 2009.

13. Dalby B, Cates S, Harris A, Ohki EC, Tilkins ML, Price PJ, et al. Advanced transfection with lipofectamine 2000 reagent: Primary neurons, siRNA, and high-throughput applications. Methods 2004; 33:95-103.

14. Deng H, Liu R, Ellmeier W, Choe S, Unutmaz D, Burkhart M, et al. Identification of a major co-receptor for primary isolates of HIV-1. Nature 1996;381:661-6.

15. Dragic T, Litwin V, Allaway GP, Martin SR, Huang Y, Nagashima KA, et al. HIV-1 entry into CD4+ cells is mediated by the chemokine receptor CC-CKR-5. Nature 1996;381:667-73.

16. Gulick RM, Mellors JW, Havlir D, Eron JJ, Gonzalez C, McMahon D, et al. Treatment with indinavir, zidovudine, and lamivudine in adults with human immunodeficiency virus infection and prior antiretroviral therapy. N Engl J Med 1997;337:734-9.

17. Jenny P, Louw M, Pakkiri D, Jacobs M. Working with HIV/AIDS. Cape Town: Juta Legal and Academic Publishers; 2006. 